\title{
Anaerobic co-digestion of coffee waste and sewage sludge
}

\author{
L. Neves, R. Oliveira, M.M. Alves * \\ Centro de Engenharia Biológica, Universidade do Minho, 4710-057 Braga, Portugal
}

Accepted 20 December 2004

Available online 16 February 2005

\begin{abstract}
The feasibility of the anaerobic co-digestion of coffee solid waste and sewage sludge was assessed. Five different solid wastes with different chemical properties were studied in mesophilic batch assays, providing basic data on the methane production, reduction of total and volatile solids and hydrolysis rate constant. Most of the wastes had a methane yield of $0.24-0.28 \mathrm{~m}^{3} \mathrm{CH}_{4(\mathrm{STP})} / \mathrm{kg} \mathrm{VS}_{\text {initial }}$ and $76-89 \%$ of the theoretical methane yield was achieved. Reduction of $50-73 \%$ in total solids and $75-80 \%$ in volatile solids were obtained and the hydrolysis rate constants were in the range of $0.035-0.063 \mathrm{~d}^{-1}$. One of the solid wastes, composed of $100 \%$ barley, achieved a methane yield of $0.02 \mathrm{~m}^{3} \mathrm{CH}_{4(\mathrm{STP})} / \mathrm{kg} \mathrm{VS}_{\text {initial}}$, reductions of $31 \%$ in total solids, $40 \%$ in volatile solids and achieved only $11 \%$ of the theoretical methane yield. However, this waste presented the highest hydrolysis rate constant. Considering all the wastes, an inverse linear correlation was obtained between methane yield and the hydrolysis rate constant, suggesting that hydrolysis was not the limiting factor in the anaerobic biodegradability of this type of waste.
\end{abstract}

(C) 2005 Elsevier Ltd. All rights reserved.

\section{Introduction}

Due to the strict legislation currently in use for landfilling, anaerobic digestion has a strong potential as an alternative treatment for biodegradable waste. The instant coffee production process involves roasting the beans and extracting the soluble fraction with hot water, giving rise to the generation of large amounts of a dark coloured liquid waste containing about $20 \%$ of insoluble solids. When instant coffee substitutes are produced, the raw material contains barley, rye, malted barley, chicory and coffee, the relative amount of each depending on the specific substitute to be produced. Whatever the raw material used, the waste is mainly composed of carbohydrate fibers such as cellulose, hemi-cellulose and also lignin (Dinsdale et al., 1996). Cellobiose and glucose are the hydrolysis products from cellulose, whereas hemicellulose hydrolyses to pentoses, hexoses and uronic

\footnotetext{
* Corresponding author. Tel.: +351 253 604400; fax: +351 253 678986

E-mail address: Madalena.alves@deb.uminho.pt (M.M. Alves).
}

acid. Lignin is highly recalcitrant and its degradation is considered the limiting step in the decomposition of lignocellulosic substrates (Pavlostathis and Girald-Gomez, 1991).

Coffee waste is produced at high temperatures $\left(70{ }^{\circ} \mathrm{C}\right)$, the $\mathrm{pH}$ is near 4 and, due to the roasting process, a number of phenol heterocyclic compounds may appear. The anaerobic digestion of coffee waste has been reported at mesophilic temperatures (Lane, 1983; Raetz, 1990) and also at thermophilic temperatures (Kida et al., 1992; Kostenberg and Marchain, 1993). Boopathy (1987) studied different inoculum sources and found that the biomass from a sewage digester appeared to acclimatise quickly to the coffee pulp. When studying the digestion of coffee waste in a continuous reactor at mesophilic temperatures, Lane (1983) found a decline in the gas production after $80 \mathrm{~d}$, due to some inhibitory compounds. Similarly, Raetz (1990) working at thermophilic temperatures in batch studies, also indicates problems in achieving stable gas production, either due to $\mathrm{pH}$ problems or inhibition. The anaerobic digestion of the liquid waste stream of instant coffee substitutes was first 
attempted by Kostenberg and Marchain (1993). The aim of their study was to evaluate the potential of the digested material as a growth medium for horticulture after thermophilic anaerobic digestion. These authors reported some problems in the experiments due to the high level of solids and to the high percentage of fiber. In spite of the experimental problems, biogas production with a composition of $70 \% \mathrm{CH}_{4}$ and relatively stable volatile fatty acids (VFA) concentrations was achieved.

All of the studies mentioned above are reported with regards to coffee waste, but most instant coffee substitutes are produced from a blend of barley, rye, malted barley, chicory and coffee. Due to the different raw matter used to produce the different substitutes, the waste composition changes sequentially, making it important to evaluate their individual performances as far as the anaerobic digestion process is concerned. Therefore, the aim of this work is to study the anaerobic biomethanation process of five wastes from instant coffee substitute production under mesophilic conditions, co-digested with the excess of activated sludge from a wastewater treatment plant located in the same factory.

\section{Materials and methods}

\subsection{Waste source}

Five "coffee" wastes from instant coffee substitute production were obtained from the Nestle factory in Avanca, Portugal. About 40 ton/d (dry matter between $13 \%$ and $22 \%$ ) of waste are, on average, produced in this factory. A wastewater treatment plant is installed in the same factory, producing an excess of activated sludge of about 3.9 ton/d with a dry matter content of $22 \%$. Table 1 shows the composition of the 5 wastes, from W1 to W5. All of the different wastes presented $\mathrm{pH}$ values between 4.5 and 5.0, and the fiber content may be up to $45 \%$ (dry weight).

The characterization of total solids (TS), volatile solids (VS) and chemical oxygen demand (COD) of each waste, and of the diluted sludge used in the assays (S), is presented in Table 2 .

Table 1

Composition of the insoluble matter of the five wastes studied

\begin{tabular}{lccllc}
\hline Waste \# & $\begin{array}{l}\text { Coffee } \\
(\%)\end{array}$ & $\begin{array}{l}\text { Barley } \\
(\%)\end{array}$ & $\begin{array}{l}\text { Rye } \\
(\%)\end{array}$ & $\begin{array}{l}\text { Malted barley } \\
(\%)\end{array}$ & $\begin{array}{l}\text { Chicory } \\
(\%)\end{array}$ \\
\hline W1 & 0 & 40 & 5 & 30 & 25 \\
W2 & 45 & 32 & 0 & 0 & 23 \\
W3 & 0 & 100 & 0 & 0 & 0 \\
W4 & 20 & 45 & 0 & 0 & 35 \\
W5 & 20 & 45 & 0 & 0 & 35 \\
\hline
\end{tabular}

Table 2

Characterization of each type of waste in TS, VS and COD

\begin{tabular}{llll}
\hline Waste \# & $\begin{array}{l}\text { TS } \\
(\mathrm{g} / \mathrm{kg} \text { waste })\end{array}$ & $\begin{array}{l}\text { VS } \\
(\mathrm{g} / \mathrm{kg} \text { waste })\end{array}$ & $\begin{array}{l}\text { COD } \\
(\mathrm{g} / \mathrm{kg} \text { waste })\end{array}$ \\
\hline W1 & $131 \pm 4$ & $127 \pm 4$ & $111 \pm 4$ \\
W2 & $217 \pm 5$ & $215 \pm 5$ & $208 \pm 9$ \\
W3 & $214 \pm 2$ & $208 \pm 2$ & $123 \pm 1$ \\
W4 & $144 \pm 8$ & $141 \pm 8$ & $130 \pm 6$ \\
W5 & $139 \pm 11$ & $136 \pm 11$ & $109 \pm 9$ \\
S & $7 \pm 1$ & $6 \pm 1$ & $6 \pm 1$ \\
\hline
\end{tabular}

\subsection{Inoculum}

The granular sludge was collected from an UASB (upflow anaerobic sludge blanket) reactor treating a brewery effluent located in Oporto, Portugal. The production of methane due to the residual substrate present

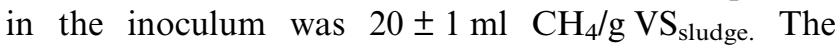
quantification of the residual methane production was performed using a pressure transducer technique (Colleran et al., 1992). The test involves monitoring of the pressure increase developed in sealed vials without substrate. Strict anaerobic conditions were maintained, using an anaerobic basal medium composed of cysteine- $\mathrm{HCl}(0.5 \mathrm{~g} / 1), \mathrm{NaHCO}_{3}(3 \mathrm{~g} / 1)$, with the $\mathrm{pH}$ adjusted to 7.0-7.2. Rezasurin was added as an indicator of redox potential. The hand held pressure transducer

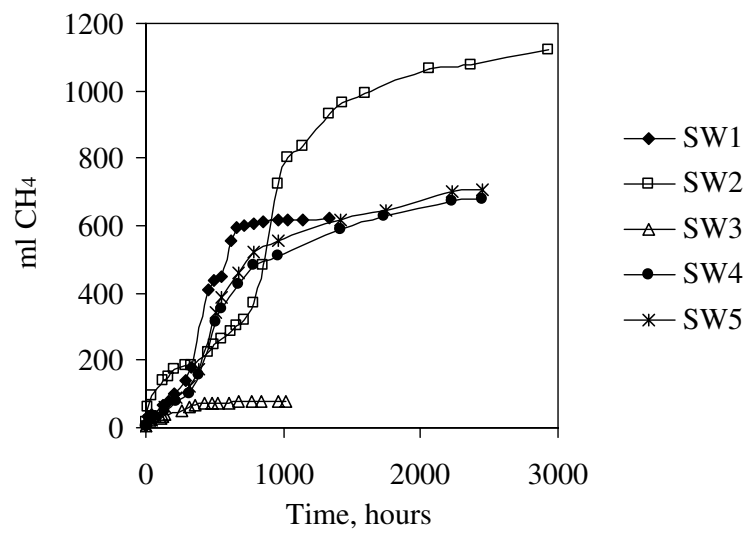

Fig. 1. Cumulative methane production during the co-digestion assays of coffee waste and sewage sludge.

Table 3

Methane yield, $\%$ of methanation, $\%$ reduction of TS and VS of the different coffee wastes in the batch assays

\begin{tabular}{lllll}
\hline Assay \# & $\begin{array}{l}\text { Methane yield } \\
\left(\mathrm{m}^{3} \mathrm{CH}_{4(\mathrm{STP})} /\right. \\
\left.\mathrm{kg} \mathrm{VS}_{\text {initial }}\right)\end{array}$ & $\begin{array}{l}\text { Methanation } \\
(\%)\end{array}$ & $\begin{array}{l}\text { Reduction } \\
\text { of TS }(\%)\end{array}$ & $\begin{array}{l}\text { Reduction } \\
\text { of VS }(\%)\end{array}$ \\
\hline SW1 & 0.24 & 76 & 73 & 78 \\
SW2 & 0.28 & 85 & 67 & 80 \\
SW3 & 0.02 & 10 & 31 & 40 \\
SW4 & 0.25 & 75 & 50 & 79 \\
SW5 & 0.25 & 89 & 54 & 75 \\
\hline
\end{tabular}


used was capable of measuring a pressure increase or decrease of two atmospheres ( 0 to $\pm 202.6 \mathrm{kPa})$ over a range of -200 to $+200 \mathrm{mV}$. The sensing element was connected to a digital panel module and the device was powered by a $9.0 \mathrm{~V} \mathrm{DC}$ transformer. The tests for the quantification of residual methane were performed in 25-ml vials, in triplicate. The volume of methane produced was corrected to the standard temperature and pressure conditions (STP).

\subsection{Batch experiments}

\subsubsection{Methane production assays}

The methane production assays were performed in $160-\mathrm{ml}$ vials, in duplicate. A constant ratio of $7 \mathrm{~g}$ $\mathrm{TS}_{\text {coffee waste }} / \mathrm{g} \mathrm{TS}_{\text {sludge }}$ was kept in the assays, which reflect the relative daily production of the two waste streams. In each assay, the ratio substrate/inoculum was kept constant at $2.3 \mathrm{~g} \mathrm{TS}$ substrate $/ \mathrm{g} \mathrm{TS}_{\text {inoculum. The }}$ $\mathrm{pH}$ was corrected to 7 , and $0.75 \mathrm{~g} \mathrm{NaHCO}_{3} / \mathrm{g} \mathrm{TS}$ was added to give suitable alkalinity. The vials were then incubated at $37^{\circ} \mathrm{C}$ under stirring conditions $(150 \mathrm{rpm})$ and the pressure increase was monitored using the above mentioned pressure transducer device. At regular time intervals, the vials were depressurised and the biogas composition was analyzed for $\mathrm{CH}_{4}$ and $\mathrm{CO}_{2}$ content. The batch assays had a total solid content in the range $6-9 \%$. The volume of methane produced was corrected to standard temperature and pressure conditions. The results from the biomethanation process were expressed in terms of methane yield $\left(\mathrm{m}^{3} \mathrm{CH}_{4} / \mathrm{kg} \mathrm{VS}\right.$ initial $)$ and in terms of percent methanation that corresponds to the percentage of methane produced relative to the biochemical methane potential (350 $1 \mathrm{CH}_{4} / \mathrm{kg} \mathrm{COD)}$.

\subsubsection{Liquid composition assays}

Parallel assays, with 500-ml working volume, were set up to assess the liquid composition in terms of soluble COD and VFA (acetate, propionate, iso-butyrate, $n$-butyrate and valerate).

\subsection{Analytical methods}

COD, TS and VS were determined according to Standard Methods (APHA, AWWA, WPCF, 1989).
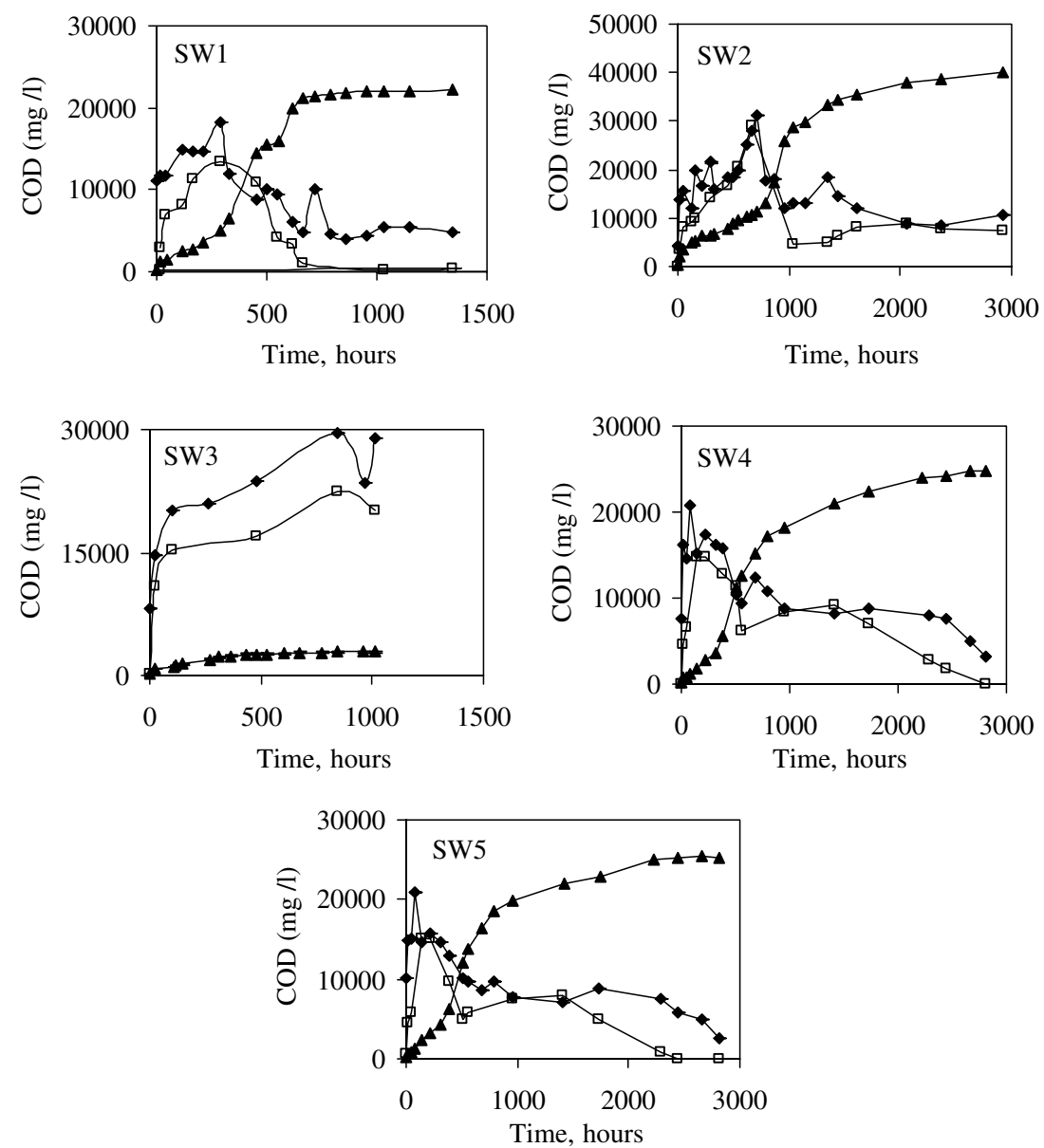

Fig. 2. Time course of soluble COD $(\bullet)$, volatile fatty acids COD $(\square)$ and methane COD $(\boldsymbol{\Delta})$. 
Methane and carbon dioxide content of the biogas was measured by gas chromatography using a Porapack Q (180 to $100 \mathrm{Mesh}$ ) column, with $\mathrm{He}$ as the carrier gas at $30 \mathrm{ml} / \mathrm{min}$ and a thermal conductivity detector. Temperatures of the detector, injector and oven were 110, 110 and $35^{\circ} \mathrm{C}$, respectively. VFA were determined by high-performance liquid chromatography using a chrompack column $(300 \times 6.5 \mathrm{~mm})$ and a mobile phase of sulphuric acid $5 \mathrm{mM}$ at $0.7 \mathrm{ml} / \mathrm{min}$. The column was set at $60{ }^{\circ} \mathrm{C}$ and the detection was by spectrophotometry at $220 \mathrm{~nm}$.

\section{Results and discussion}

Fig. 1 shows the methane production curves obtained for the different assays.

Table 3 shows the methane yield, the percentage of methanation, and the reduction of TS and VS obtained in each assay, after the correction of the methane production due to the residual substrate present in the inoculum (blank assays).
Among the different wastes, the assay SW2 showed the highest methane yield, $0.28 \mathrm{~m}^{3} / \mathrm{kg} \mathrm{VS}_{\text {initial, }}$ which agrees with the higher VS reduction $(80 \%)$ and the higher initial COD content of this waste. This assay also achieved $85 \%$ of the theoretical methane production, although it took $144 \mathrm{~d}$ to attain the "plateau". In the assays SW1, SW4 and SW5, similar methane yields were obtained $\left(0.24-0.25 \mathrm{~m}^{3} / \mathrm{kg} \mathrm{VS}\right.$ initial $)$, the VS reduction was in the range $75-79 \%$ and the percentage of methanation in the range $75-89 \%$. The assay SW1 was faster than the others, since it stabilised after about $50 \mathrm{~d}$, whereas the other assays needed about $100 \mathrm{~d}$.

The methane yield achieved in assay SW3 was very poor $\left(0.02 \mathrm{~m}^{3} \mathrm{CH}_{4} / \mathrm{kg} \mathrm{VS}\right)$, which corresponded to only $11 \%$ of the theoretical methane production. This is not surprising because carbohydrates from barley are about $69 \%$ composed by fiber (http://www.nutritiondata.com/ facts-001-02s04dq.html), being about 6\% indigestible fiber (Potter and Hotchkiss, 1995). In this assay, the lowest values of TS and VS reduction were obtained.

Fig. 2 shows the evolution of methane, VFA and soluble COD, all expressed as COD.
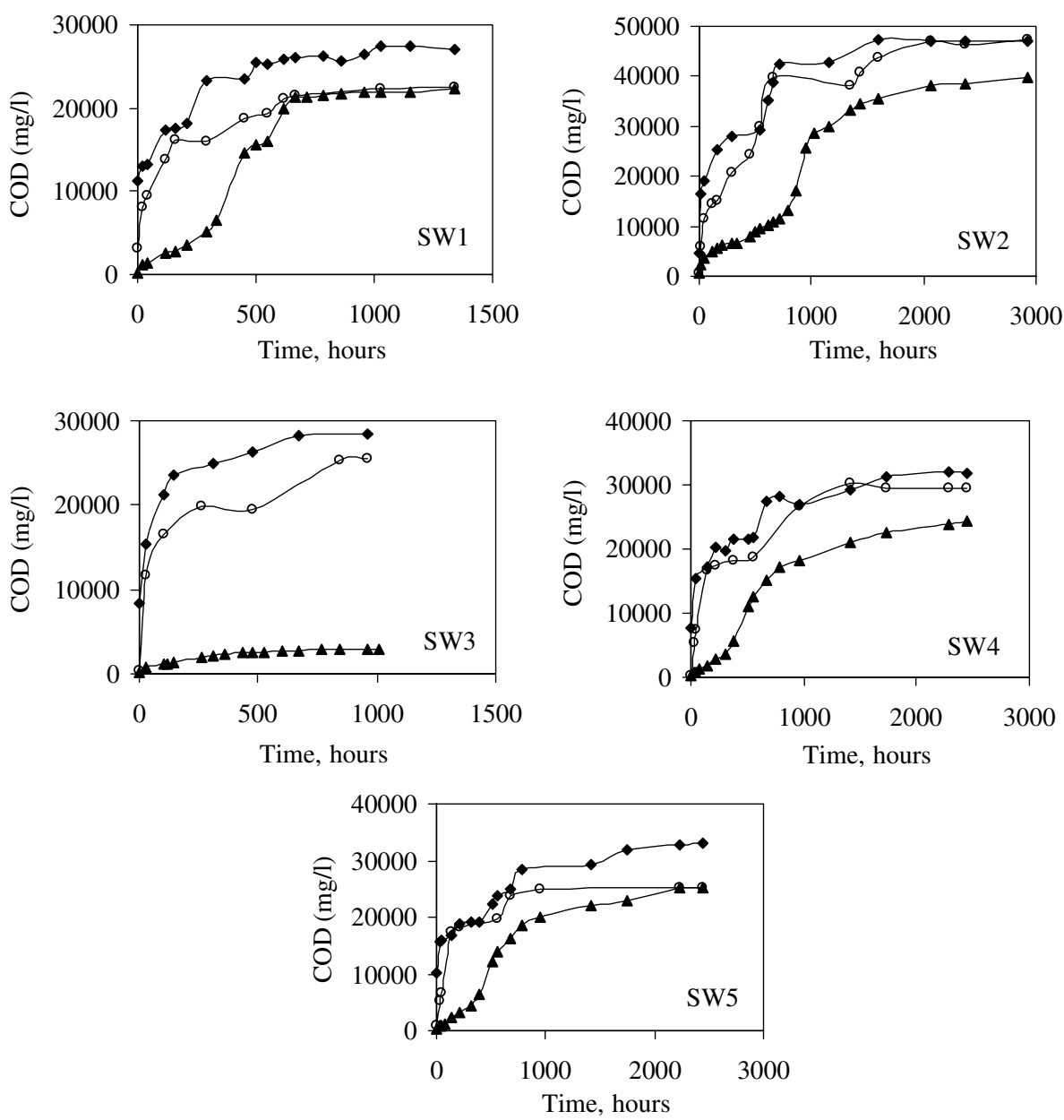

Fig. 3. Cumulative hydrolyzed COD $(\diamond=$ methane + soluble COD), acidified COD $(0=$ methane + VFA $)$ and methane COD $(\boldsymbol{\Delta})$. 
The assay that reached the higher concentration in VFA was SW2 (29 g/l) and this value did not seem to inhibit the subsequent methanogenic process. The poor methane yield of $11 \%$ obtained in assay SW3 was likely due to the presence of products from the hydrolysis of complex heterocyclic compounds rather than to the levels of VFA which peaked at $22 \mathrm{~g} / \mathrm{l}$, a value lower than in assay SW2. All of the other assays achieved VFA concentrations of around $13-15 \mathrm{~g} / \mathrm{l}$. The final $\mathrm{pH}$ in all the assays was in the range of 7.3-7.8 indicating that irreversible acidification did not occur. At the end of the assays, the VFA concentration was very low (almost near zero in some of the assays), except for SW3 that was still at $20 \mathrm{~g} / 1$, about $41 \mathrm{~d}$ after beginning the test.

Fig. 3 shows the cumulative methane as COD, hydrolysed COD and acidified COD for all the assays. From this figure, the relative kinetics of hydrolysis, acidification and methanation can be assessed.

In general, it is accepted that hydrolysis of particulate organic matter is the rate-limiting step in the anaerobic digestion of particulate substrates. However, in the present work this did not occur, since the curve of cumulative hydrolysed COD increased at a higher rate than the corresponding cumulative methane production curve.

For all of the wastes, $84-97 \%$ of the initial COD was hydrolysed, but the percentage of methanation was lower, in the range $75-89 \%$, with the exception of SW3 where only $10 \%$ of methanation was observed.

Although the rate of hydrolysis is a function of $\mathrm{pH}$, temperature, concentration of hydrolytic bacteria, and type of particulate organic matter (Pavlostathis and Girald-Gomez, 1991), how the physicochemical properties of particulate organic substrates quantitatively affect the rate of hydrolysis (Veeken and Hamelers, 1999) is not well understood. In this study, all of the parameters mentioned above were the same in all of the assays, except the physicochemical properties of the organic waste. The hydrolysis rate constant for each assay was determined, assuming first order kinetics (Table 4).

Fig. 4 shows a negative correlation between the hydrolysis rate constant and the methane yield for all the assays.

This indicates that when hydrolysis was faster, the methane yield was lower, likely because the faster hydrolysis induced a more important accumulation of intermediates potentially toxic to the methanogenic

Table 4

Hydrolysis constant rates (assuming first order kinetics)

\begin{tabular}{ll}
\hline Assay \# & Hydrolysis rate constant $\left(\mathrm{d}^{-1}\right)$ \\
\hline SW1 & 0.063 \\
SW2 & 0.035 \\
SW3 & 0.084 \\
SW4 & 0.040 \\
SW5 & 0.036 \\
\hline
\end{tabular}

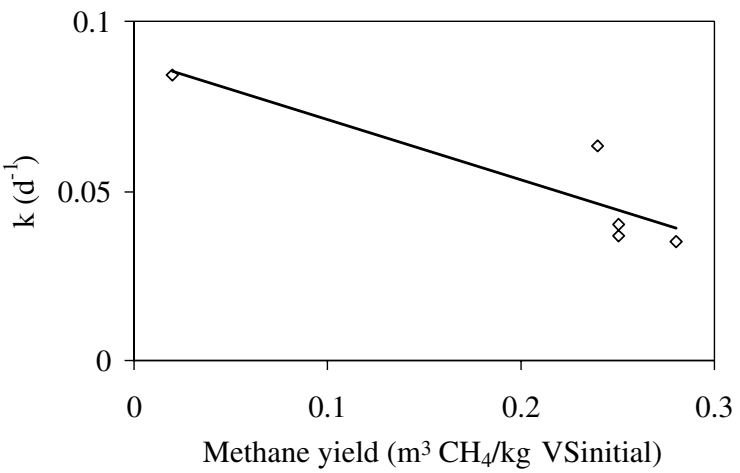

Fig. 4. Linear correlation between the hydrolysis constant rates and the methane yields.

population. Veeken and Hamelers (1999), when studying the anaerobic biodegradability of six components of biowaste containing lignocellulosic material, found that grass was less biodegradable $(\approx 47 \%)$ than leaves $(\approx 35 \%)$, although having a higher hydrolysis rate constant under mesophilic conditions. According to Tong et al. (1990), biodegradability depends on the structure of the lignocellulosic complex. Cellulose is readily degradable but becomes less degradable or even refractory when incorporated in a lignocellulosic complex. Moreover, Azhar and Stuckey (1994) studied the influence of chemical structure of instant coffee wastes on anaerobic catabolism and found that the individual chemical structure of compounds greatly influences and determines the rate and mechanisms of methanogenic degradation.

\section{Conclusions}

When studying five coffee wastes from the production of instant coffee substitutes, methane yields in the range of $0.24-0.28 \mathrm{~m}^{3} / \mathrm{kg} \mathrm{VS}$ initial were obtained with the exception of a barley-rich waste (SW3) that achieved

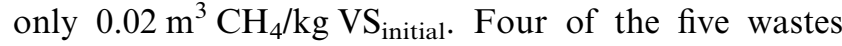
(SW1, SW2, SW4, SW5) also presented a high reduction of TS $(50-73 \%)$ and VS (75-80\%), as well as $75-89 \%$ of the theoretical methane potential $(3501 / \mathrm{kg}$ COD removed). Hydrolysis constant rates in the range of $0.035-0.063 \mathrm{~d}^{-1}$ were obtained.

In the authors' point of view, these wastes (SW1, SW2, SW4 and SW5) should be treated by anaerobic co-digestion rather than landfilled.

The SW3 waste achieved a methanation of $10 \%$ and reduction of TS and VS of $31 \%$ and $40 \%$, respectively. However, this waste presented the highest hydrolysis rate constant $\left(0.084 \mathrm{~d}^{-1}\right)$, indicating that hydrolysis was not, in this case, the rate limiting step in the anaerobic digestion process. This was evidenced by plotting the hydrolysis rate constants and the methane yields that were inversely correlated, suggesting that intermediates 
formed during the hydrolysis step were likely toxic to the methanogenic population.

\section{Acknowledgements}

The authors thank the FCT for the financial support given to Lúcia Neves through the project POCTI/1999/ CTA/36524.

\section{References}

APHA, AWWA, WPCF, 1989. Standard methods for the examination of water and wastewater, 17th ed., Washington, DC.

Azhar, N.G., Stuckey, D.C., 1994. The influence of Chemical structure on anaerobic catabolism of refractory compound: a case study of instant coffee wastes. Wat. Sci. Technol. 30 (12), 223-232.

Boopathy, R., 1987. Inoculum source for anaerobic fermentation of coffee pulp. Appl. Microbiol. Biotechol. 26, 588-594.

Colleran, E., Concannon, F., Golde, T., Geoghegan, F., Crumlish, B. Killile, E., Henry, M., Coates, J., 1992. Use of methanogenic activity tests to characterize anaerobic sludges, screen for anaerobic biodegradability and determine toxicity thresholds against individual anaerobic trophic groups and species. Wat. Sci. Technol. 25, $31-40$.

Dinsdale, R.M., Hawkes, F.R., Hawkes, D.L., 1996. The mesophilic and termophilic anaerobic digestion of coffee waste containing coffee grounds. Wat. Res. 30 (2), 371-377 http://www.nutritiondata.com/facts-001-02s04dq.html .

Kida, K., Ikbal, Sonada, Y., 1992. Treatment of coffee waste water by slurry state anaerobic digestion. J. Ferment. Biongng. 73, 390-395.

Kostenberg, D., Marchain, U., 1993. Solid waste from the instant coffee industry as a substrate for anaerobic thermophilic digestion. Wat. Sci. Technol. 27 (2), 97-107.

Lane, A.G., 1983. Anaerobic digestion of spent coffee grounds. Biomass 3, 247-268.

Pavlostathis, S.G., Girald-Gomez, E., 1991. Kinetics of anaerobic treatment: a critical review. Crit. Rev. Environm. Control 21, 411490

Potter, N.N., Hotchkiss, J.H., 1995. Food Science, 5th ed. Chapman \& Hall, London, p. 382.

Raetz, E., 1990. Anaerobic Digestion of wastes; spent coffee grounds. Nestlé Research Centre no. 42.

Tong, X., Smith, L.H., McCarty, P.L., 1990. Methane fermentation of selected lignocellulosic materials. Biomass 21, 239-255.

Veeken, A., Hamelers, B., 1999. Effect of temperature hydrolysis rate of selected biowaste components. Biores. Technol. 69, 249-254. 